\title{
HUBUNGAN PENGUASAAN KOSAKATA DENGAN KETERAMPILAN MENULIS KARANGAN DESKRIPTIF BAHASA JERMAN SISWA
}

\author{
Hasrar $^{1}$, Ambo Dalle ${ }^{2}$, dan Misnawaty Usman ${ }^{3}$ \\ Fakultas Bahasa dan Sastra Universitas Negeri Makassar \\ Email: hasrarlee@gmail.com ${ }^{1}$
}

\begin{abstract}
ABSTRAK
Penelitian ini bertujuan untuk mengetahui hubungan antara penguasaan kosakata dengan keterampilan menulis karangan deskriptif bahasa Jerman. Teknik pengumpulan data pada penelitian ini dilakukan dengan tes tertulis. Data dianalisis melalui korelasi Product Moment. Populasi penelitian ini adalah siswa kelas XI IPA yang yang terdiri dari 1 kelas, berjumlah 20 orang. Sampel dipilih menggunakan teknik Total Sampling yaitu seluruh siswa kelas XI IPA yang berjumlah 20 siswa. Hasil penelitian ini menunjukkan bahwa ada hubungan yang signifikan antara penguasaan kosakata dengan keterampilan menulis karangan deskriptif bahasa Jerman Siswa kelas XI IPA SMA Karya Sahari Bulukumba $\left(r_{h}=0,609>r_{t}=0,444\right)$.
\end{abstract}

Kata Kunci: Penguasaan Kosakata, Keterampilan Menulis, Karangan Deskriptif

\begin{abstract}
The purpose of the study was to know the relationship between vocabulary mastery with a descriptive essay writing skills of language Germany. Data was collected using writing skill test. Data were analyzed through the Product Moment correlation. The population of this research is the grade XI IPA which consisting of 1 class, numbered 20 people. The sample was selected using the technique of Total Sampling namely whole grade XI IPA that add up to 20 students. The results of this study showed that there is a significant relationship between vocabulary mastery with a descriptive essay writing skills of language Germany grade XI IPA SMA Karya Sahari Bulukumba $(\mathrm{rh}=0,609>\mathrm{rt}=0,444)$.
\end{abstract}

Keywords: Mastery of Vocabulary, Writing Skills, Descriptive Essay

\section{PENDAHULUAN}

Perkembangan zaman menuntut manusia untuk ikut berkembang dan salah satu aspek perkembangan yang menjadi tuntutan adalah komunikasi. Seseorang berkomunikasi dengan individu lain menggunakan bahasa. Bahasa merupakan media yang sangat penting dalam berkomunikasi untuk menyampaikan informasi, ide atau gagasan yang dapat mempererat hubungan sosial antar individu. Kemampuan berbahasa merupakan tuntutan yang sangat penting di era komunikasi global, khususnya penguasaan bahasa asing, sebab dengan penguasaan bahasa asing yang baik perkembangan informasi dan teknologi dunia dapat diketahui dan diikuti perkembangannya.

Saat ini pembelajaran bahasa asing telah banyak diajarkan di Indonesia mulai dari jenjang Sekolah Dasar hingga Sekolah Menengah Atas. Bahasa asing yang menjadi mata pelajaran di sekolah yaitu bahasa 
Inggris, Jerman, Prancis, Jepang, Mandarin, Arab dan lain-lain. Bahasa Jerman menjadi salah satu bahasa asing yang penting untuk diketahui mengingat saat ini negara Jerman banyak melakukan kerjasama bilateral dengan Indonesia. Pada pembelajaran bahasa Jerman terdapat empat kompetensi berbahasa yang diajarkan yakni mendengar (Hören), berbicara (Sprechen), membaca (Lesen), dan menulis (Schreiben). serta ditunjang dua aspek kemampuan, yaitu kosakata (Wortschatz) dan tata bahasa (Strukturen).

Menulis merupakan salah satu keterampilan berbahasa yang penting untuk dikuasai siswa (Mantasiah et all, 2017; Qalbi et all, 2017). Oleh karena itu, keterampilan menulis juga harus dilatih secara intensif. Hal ini dikarenakan keterampilan menulis bersifat produktif, artinya menghasilkan suatu produk yaitu tulisan. Dengan keterampilan menulis siswa dapat menuangkan pikiran, gagasan, dan ide-ide kreatif dalam bentuk tulisan. Oleh karena itu, menulis adalah kemampuan seseorang dalam menambah gagasan pikirannya kepada orang atau pihak lain dengan media tulisan.

Menyadari pentingnya kegiatan menulis, maka perlu ditanamkan kosakata kepada siswa sedini mungkin. Hal ini akan tercapai apabila bimbingan menulis dalam pengajaran bahasa Jerman di sekolah-sekolah diberikan secara sistematis dan terus menerus oleh guru bahasa Jerman. Untuk dapat menulis karangan, siswa harus mampu menguasai atau memperbanyak kosakata, Kosakata dan tata bahasa sangat penting dalam mepelajari bahasa Jerman, baik dalam pelajaran menulis, percakapan maupun membaca, karena Semakin banyak kosakata yang dikuasai seseorang, maka semakin banyak pula ide atau gagasan yang dapat dituangkan dalam bentuk tulisan.
Pembelajaran menulis karangan di Sekolah Menengah Atas (SMA) dalam bahasa Jerman merupakan salah satu dari kegiatan pembelajaran. Menulis karangan menuntut pengalaman, waktu, latihan, dan pengajaran langsung. Melalui pengalaman yang dirasakan akan lebih memudahkan siswa dalam menuangkan pikiran, gagasan dan ide dalam bentuk karangan. Ada beberapa jenis karangan salah satunya adalah karangan deskriptif. Karangan deskriptif merupakan suatu tulisan atau karangan yang menggambarkan atau memaparkan suatu objek, lokasi, keadaan atau benda dengan kata-kata.

Berdasarkan observasi yang dilakukan di SMA Karya Sahari Bulukumba diperoleh informasi bahwa masih banyak siswa yang mengalami kesulitan dalam menulis karangan bahasa Jerman. Apabila siswa diberi tugas menulis karangan atau dialog, siswa cenderung menggunakan konstruksi kalimat yang sama bahkan hanya meniru dialog atau teks yang sudah ada. Kesulitan itu disebabkan karena minat belajar bahasa Jerman siswa yang masih rendah dan minimnya penguasaan kosakata. Minat belajar tentunya berkorelasi positif dengan hasil belajar peserta didik (Yusri et all, 2018; Romadloni et all, 2017). Kondisi seperti ini cukup menyulitkan dalam upaya menciptakan suatu pembelajaran yang produktif dan dinamis yang pada hakikatnya akan mempengaruhi rendahnya kualitas pendidikan.

Beberapa penelitian sebelumnya yang relevan dengan penelitian ini yang dilakukan oleh Muslim (2012) menyatakan bahwa penguasaan kosakata siswa bahasa Jerman kelas XI SMAN Bontotiro Kabupaten Bulukumba termasuk dalam kategori kurang (35,29\%), penelitian lain dari Destari (2013) 
dalam penelitiannya menyimpulkan bahwa keterampilan menulis bahasa Jerman siswa kelas XI IPA SMA 3 Palangkaraya termasuk kategori rendah dengan persentase $34,5 \%$. Rahman (2015) menyimpulkan bahwa keterampilan menulis yang berhubungan dengan penguasaan gramatik siswa termasuk dalam kategori cukup dengan nilai rata-rata 23,8 atau dengan persentase $72,39 \%$. Nurliana (2015) dalam penelitiannya menyimpulkan bahwa terdapat Hubungan antara Penguasaan Kosakata dengan Keterampilan Menulis Karangan Sederhana bahasa Jerman. Berdasarkan koefiensikoefiensi korelasi yang diperoleh dapat ditulis: $\left(r_{t} 0,421 \geq r_{t} 0,355\right)$. Berdasarkan uraian di atas, maka perlu dilakukan penelitian untuk mengetahui kontribusi penguasaan kosakata terhadap keterampilan menulis karangan deskriptif yang dilakukan di SMA Karya Sahari Bulukumba.

\section{KOSAKATA}

Kosakata merupakan salah satu unsur yang sangat penting. Kosakata suatu bahasa ialah perbendaharaan kata-kata dalam suatu bahasa yang digunakan oleh seseorang dalam kegiatan menulis dan berbicara. Tarigan (2011:3) menjelaskan bahwa kosakata ialah kata-kata yang tidak mudah berubah atau sedikit sekali kemungkinannya dikutip dari bahasa lain. Sedangkan menurut Hiebert dan Kamil (2005:3) mengatakan "Generally, vocabulary ist the knowledge of meanings of words" dalam artian adalah kosakata dapat didefenisikan sebagai ilmu pengetahuan tentang arti kata.

Selanjutnya Djiwandono (2008:126) mengemukakan pengertian kosakata ialah sebagai pembendaharaan kata-kata dalam berbagai bentuknya yang meliputi: kata-kata lepas dengan atau tampa imbuhan, dan kata- kata yang merupakan gabungan dari katakata yang sama atau berbeda masing-masing dengan artinya sendiri. Definisi lain yang senada dengan pendapat di atas dikemukakan oleh Scholl dalam Harum (2015: 9) bahwa Als Wortschatz bezeichnet man die Gesamheit der Wörter einer Sprache; Gesamheit der Wörter, die jemanden anwenden kann, dalam hal ini kosa kata menunjukkan keseluruhan kata-kata suatu bahasa; keseluruhan kata-kata yang dapat digunakan oleh seseorang. Dari beberapa definisi tentang kosakata di atas, dapat disimpulkan bahwa kosakata merupakan semua kata yang terdapat dalam suatu bahasa dan merupakan pembendaharaan kata yang dimiliki oleh seseorang.

\section{KETERAMPILAN MENULIS}

Keterampilan adalah kemahiran seseorang yang dimilki dari hasil latihan terus menerus dalam melakukan suatu hal. Keterampilan juga dapat dikatakan sebagai kemapuan untuk menggunakan akal, ide, pikiran, gagasan dan kreativitas dalam mengerjakan, mengubah ataupun, membuat sesuatu menjadi lebih bermakna sehingga menghasilkan sebuah nilai hasil dari pekerjaan itu. Seperti yang dikemukakan oleh Tarigan (2013: 3) keterampilan adalah kemampuan yang dimiliki oleh seseorang dari hasil praktik dan banyak latihan. Menurut Zainurrahman (2013: 12) bahwa keterampilan bahasa dibagi menjadi dua jenis, yaitu keterampilan yang biasa diperoleh secara alami dan keterampilan yang hanya diperoleh melalui latihan-latihan dan penguasaan konsep tertentu. Lebih lanjut Tarigan (2013: 1) berpendapat bahwa keterampilan itu erat pula hubungan dengan proses-proses yang mendasari bahasa. bahasa seseorang mencerminkan pikirannya. 
Semakin terampil seseorang berbahasa, semakin cerah dan jelas pula jalan pikiranya. Keterampilan hanya dapat diperoleh dan dikuasiai dengan jalan praktik dan banyak pelatihan. Melatih keterampilan bebahasa berarti melatih pula keterampilan berfikir.

Senada dengan pendapat tersebut Junus dan Junus (2010:10) mengemukakan bahwa keterampilan ialah kemampuan yang disertai dengan kemahiran melakukan sesuatu. Untuk memilikinya diperlukan latihan yang teratur bahkan remedial. Berdasarkan beberapa pendapat di atas dapat disimpulkan bahwa keterampilan merupakan suatu keahlian atau kecakapan yang dimiliki oleh masing-masing individu dan terampil merupakan kepandaian melakukan sesuatu dengan cepat dan benar.

Menurut Tarigan (2013:3) menulis merupakan suatu keterampilan berbahasa yang dipergunakan untuk berkomunikasi secara tidak langsung, tidak secara tatap muka dengan orang lain. Menulis merupakan suatu kegiatan yang produktif dan ekspresif. Selain itu, Azis (2009:7) berpendapat bahwa menulis pada hakekatnya adalah suatu proses yang menggunakan lambang-lambang (huruf) untuk menyusun, mencatat, dan mengkomunikasikan serta dapat menampung aspirasi yang dapat menghibur, serta memberi informasi, dan mengubah pengetahuan. Sedangkan Dalman (2015:4) menulis adalah proses penyampaian pikiran, angan-angan, perasaan dalam bentuk lambang/tanda/tulisan yang bermakna. Berdasarkan beberapa pendapat di atas dapat disimpulkan bahwa menulis adalah kegiatan komunikasi secara tidak langsung yang dilakukan untuk menyampaikan informasi serta dapat menghibur.

\section{KARANGAN DESKRIPSI}

Jauhari (2013) menjelaskan bahwa kata deskripsi berasal dari bahasa Latin description, artinya menggambarkan. Menggabarkan benda atau peristiwa dengan cara memberikan atau mengindentifikasi bagian-bagiannya berikut karakteristiknya. Karangan jenis ini bermaksud memberikan kesan kepada pembaca sehingga dapat membayangkan apa yang sedang dibaca. Suparmo dan Yunus dalam Dalman (2015:94) mengemukakan bahwa deskripsi adalah suatu bentuk karangan yang melukiskan sesuai dengan keadaan sebenarnya, sehingga pembaca dapat mencitrai (melihat, mendengar, mencium, dan merasakan) apa yang dilukiskan itu sesuai dengan citra penulisannya.

Menurut Dalman (2014:94) karangan deskripsi merupakan karangan yang melukiskan atau menggambarkan suatu objek atau peristiwa tertentu dengan kata-kata secara jelas dan terperinci sehingga pembaca seolah-olah turut merasakan atau mengalami langsung apa yang dideskripsikan oleh penulis. Selanjutnya, Semi (2007:66) menjelaskan bahwa karangan deskripsi adalah tulisan yang tujuannya untuk memberikan rincian atau detail tentang objek sehingga dapat memberi pengaruh pada emosi dan menciptakan imajinasi pembaca bagaikan melihat, mendengar, atau merasakan langsung apa yang disampaikan penulis. Dari pendapat di atas dapat disimpulkan bahwa karangan deskripsi adalah suatu karangan yang berisi perincianperincian yang jelas tentang suatu objek dan dapat menimbulkan pesan dan kesan bagi pembacanya. 


\section{METODE PENELITIAN}

Dalam penelitian ini menggunakan dua variabel yaitu penguasaan kosakata sebagai variabel bebas (X) dan kemampuan menulis karangan deskriptif sebagai variabel terikat (Y). Penelitian ini merupakan penelitian deskriptif korelasi yang bertujuan mengetahui hubungan antara variabel (Jufri, 2017; 2007). Variabel dalam hal ini adalah penguasaan kosakata dengan keterampilan menulis karangan deskriptif siswa kelas XI SMA Karya Sahari Bulukumba. Penguasaan kosakata yang dimaksud adalah kemampuan siswa dalam menggunakan ragam kata dalam bahasa Jerman. Kemampuan tersebut meliputi: 1) Tes mencocokkan kata dengan arti) 2) Tes penggunaan kata sifat, 3) Tes penggunaan kata kerja dan, 4) Tes penggunaan kata penghubung.

Sedangkan keterampilan menulis yang dimaksud adalah keterampilan menulis sebuah karangan deskripsi dengan tema yang telah disediakan yaitu tema Die Familie dengan bantuan kata kunci yang telah disediakan oleh peneliti dengan memperhatikan 2 aspek penilain yaitu aspek komunikatif dan aspek tata bahasa. Populasi dalam penelitian ini adalah seluruh siswa kelas XI IPA SMA Karya Sahari Bulukumba, yang terdiri dari 1 kelas dengan total siswa 20 orang. Sampel dalam penelitian ini adalah siswa kelas XI IPA SMA Karya Sahari Bulukumba berjumlah 20 orang yang diambil secara tehnik total sampling (sampel total). Data yang diperoleh dari tes penguasaan kosakata dan keterampilan menulis karangan deskriptif diuji dengan menggunakan rumus korelasi Product Moment.

\section{HASIL DAN PEMBAHASAN}

\section{Hasil Analisis Data Tes Penguasaan Kosakata}

Berdasarkan analisis data penelitian, maka ditemukan 6 kelas interval, dari 20 siswa yang menjadi sampel diperoleh 2 siswa (10\%) berada pada interval 21-25, 3 siswa (15\%) berada pada interval 26-30, 6 siswa (30\%) berada pada interval 31-35, 4 siswa (20\%) berada pada interval 36-40, 2 siswa (10\%) berada pada interval 41-45, dan 3 siswa $(15 \%)$ yang berada pada interval 46 50. Ini berarti bahwa dari 20 siswa yang menjadi sampel diperoleh kelas interval yang memiliki frekuensi tertinggi yaitu 31-35 dengan frekuensi 6 siswa (30\%). Temuan ini menunjukkan bahwa tingkat penguasaan kosakata bahasa Jerman siswa kelas XI IPA SMA Karya Sahari Bulukumba berada pada kategori Baik dengan rata-rata 35,3 dan memiliki presentase sebesar $70,6 \%$. Sehingga dapat disimpulkan bahwa penguasaan kosakata siswa sudah cukup memadai meskipun dalam pengerjaannya terdapat beberapa kesalahan.

\section{Hasil Tes Keterampilan Menulis Karangan Deskriptif}

Berdasarkan analisis data penelitian, maka ditemukan 6 kelas interval, dari 20 siswa yang menjadi sampel diperoleh 1 siswa (5\%) berada pada interval 14-23, 5 siswa (25\%) berada pada interval 24-33, 6 siswa (30\%) berada pada interval 34-43, 0 siswa (0\%) berada pada interval 44-53, 5 siswa (25 $\%$ ) berada pada interval 54-63, dan 3 siswa (15\%) yang berada pada interval 64-73. Ini berarti bahwa dari 20 siswa yang menjadi sampel diperoleh kelas interval yang memiliki frekuensi tertinggi yaitu 34-43 dengan frekuensi 6 siswa (30\%).

Temuan ini menunjukkan bahwa keterampilan menulis karangan deskriptif 
bahasa Jerman siswa kelas XI IPA SMA Karya Sahari Bulukumba berada pada kategori Cukup dengan rata-rata 45,75 dan memiliki persentase sebesar $45,75 \%$. Sehingga dapat di simpulkan bahwa keterampilan menulis karangan deskriptif bahasa Jerman siswa belum memadai karena siswa masih banyak melakukan kesalahan baik secara leksik, morfologis, sintaksis, dan ortografis dan juga menganggu urutan logika dan pemahaman dalam karangan deskriptif.

Data hasil penelitian pada tes penguasaan kosakata terdiri atas empat jenis tes. Tes tersebut adalah tes mencocokan arti kata, kata sifat (Adjektiv), kata kerja (Verb), dan kata penghubung (Konjungtion). Skor maksimal pada tes tersebut adalah 50. Berdasarkan hasil analisis data, dapat diketahui bahwa skor rata-rata yang diperoleh siswa pada tes mencocokkan arti kata adalah 11,85 (79\%), selanjutnya pada tes menyusun kata sifat adalah 7,1 (71\%), kemudian tes menentukan kata kerja 8,45 $(56,33 \%)$ dan pada tes menentukan kata penghubung adalah 8,45 (79\%).

Data hasil penelitian pada tes keterampilan menulis karangan deskriptif terdiri dari dua aspek. Kedua aspek tersebut ialah aspek komunikatif dan aspek tata bahasa. skor maksimal berdasarkan dua aspek tersebut adalah 7 setelah dikonversi menjadi 100. Berdasarkan hasil analisis data, dapat diketahui bahwa skor rata-rata yang diperoleh siswa pada aspek komunikatif adalah 1,45 (48,33\%) dan pada aspek tata bahasa adalah $1,75(43,75 \%)$. Berdasarkan analisis data, dapat diketahui bahwa skor rata-rata yang diperoleh siswa pada tes penguasaan kosakata adalah 35,3 dengan tingkat penguasaan $70,6 \%$ dan skor rata-rata pada tes keterampilan menulis karangan deskriptif bahasa Jerman adalah 45,75 dengan tingkat keterampilan sebesar 45,75\%.

Skor yang diperoleh siswa pada penguasaan kosakata dan keterampilan menulis karangan deskriptif selanjutnya dianalisis dengan menggunakan teknik korelasi Product Moment, dari hasil perhitungan diperoleh hasil bahwa $\mathrm{r}_{\text {hitung }}$ lebih besar daripada $r_{\text {tabel }}\left(r_{h}>r_{t}\right)$ yaitu 0,609> 0,444 . Dengan demikian, dapat disimpulkan bahwa terdapat korelasi yang signifikan antara penguasaan kosakata dengan keterampilan menulis karangan deskriptif bahasa Jerman. Penguasaan kosakata memegang peranan penting terhadap keterampilan menulis karangan, karena dalam membuat karangan terjadi transfer ide dan gagasan kepada pembaca. Dalam proses penyampaian gagasan tersebut seorang siswa harus memaparkan dan mendeskripsikan ide dan gagasannya dengan kata-kata tentang suatu benda, tempat, suasana, keadaan atau aktivitas objek yang mereka lihat. Sehingga siswa dituntut untuk memiliki penguasaan kosakata yang luas agar mampu mendeskripsikan ide dan gagasannya dalam bentuk karangan.

Siswa yang memiliki sedikit penguasaan kosakata cenderung lebih ribut dan banyak tanya selama proses pembuatan karangan berlangsung. Berbeda dengan siswa yang penguasaan kosakatanya luas ia akan lebih mudah dan cepat dalam membuat karangan. Dengan demikian dapat dikatakan bahwa siswa yang penguasaan kosakatanya rendah membutuhkan waktu yang lama dalam menghasilkan sebuah karangan dan yang penguasaan kosakatanya banyak cenderung membutuhkan waktu yang lebih singkat dalam proses pembuatan karangan deskripsi dalam bahasa Jerman. Selain itu kualitas hasil karangan pun dapat dibedakan. 
Siswa yang memiliki penguasaan kosakata yang luas dapat menghasilkan kualitas karangan yang lebih baik dibandingkan siswa yang tidak memiliki penguasaan kosakata yang luas.

Berdasarkan penjelasan di atas dapat disimpulkan bahwa keterampilan menulis karangan deskripsi bahasa Jerman bukan hanya dipengaruhi oleh penguasaan kosakata saja, melainkan ada banyak faktor lain yang memengaruhi keterampilan siswa dalam menulis karangan deskripsi bahasa Jerman. Faktor-faktor tersebut antara lain adalah penguasaan tata bahasa yang meliputi: tanda baca, susunan kata, struktur kalimat, ejaan dan tulisan. Sehingga dapat disimpulkan bahwa temuan penelitian ini yang mengatakan ada hubungan antara penguasaan kosakata dengan keterampilan menulis karangan deskriptif bahasa Jerman, sejalan dengan teori yang dikemukakan oleh Tarigan (2011:2) yang mengatakan bahwa kualitas keterampilan berbahasa seseorang tergantung pada kualitas dan kuantitas kosakata yang dimilikinya.

\section{KESIMPULAN}

Tingkat penguasaan kosakata bahasa Jerman siswa adalah 70,6\% dengan nilai ratarata sebesar 35,3 dan termasuk kategori Baik. Tingkat keterampilan menulis karangan deskriptif bahasa Jerman siswa adalah $45,75 \%$ dengan nilai rata-rata sebesar 45,75 dan termasuk kategori Cukup. Terdapat hubungan posistif antara penguasaan kosakata dengan keterampilan menulis karangan deskriptif bahasa Jerman. Hubungan ini ditunjukkan dengan koefiensi korelasi sebesar 0,609 yang termasuk pada kategori Kuat.

\section{DAFTAR PUSTAKA}

Annisa, Meidany. (2015). Jago Kuasai bahasa Jerman. Yogyakarta: Pustaka Baru Press

Azis, Abdul. (2009). Menulis Lanjut. Garut: Yayasan Al-Fatih.

Bolton, Sylbylle. (1995). Problem der Leistungmessung.München: Goethe Institute Langenscheid.

Clamer, F \&Heilmann, E.G. (2007). Deutsch als Fremdsprache (Übungsgramatik für die Grundstufe). GermanyDartmann: VerlagLiebaug.

Dalman. (2015). Keterampilan Menulis. Jakarta : RajaGrafindo Persada.

Destari, Paramita. (2013). Kontribusi Penguasaan Struktur Kalimat dan Kosakata terhadap Kemampuan Menulis bahasa Jerman Siswa Kelas XI SMA Negeri 3 Palangkaraya. Yogyakarta: Fakultas Bahasa dan Seni Universitas Negeri Yogyakarta.

Djiwandono, M.Soenardi. (2008). Tes Bahasa. Jakarta: PT Indeks.

Djiwandono, Soenardi. (2011). Tes Bahasa (Pegangan bagi Pengajar Bahasa). Jakarta: PT Indeks.

Djiwandono, Soenardi. (2011). Tes Bahasa

(Pegangan bagi Pengajar Bahasa).

Jakarta: PT Indeks.

Gie, T.L. (2002). Terampil mengarang. Yogyakarta: Andi.

Harum, Ardianus. (2015). Hubungan antara

Penguasaan Koskata dengan

Kemampuan Membaca Memahami

Teks Bahasa Jerman Kelas XII Ipa 7

Sma Negeri Makassar. Makassar :

FBS Universitas Negeri Makassar.

Hiebert, Elfrieda H dan Michael L. Kamil. (2005). Teaching and Learning Vocabulary. London: Lawrence Erlbaum Associates, Publisher. 
Jauhari, Heri. (2013). Terampil Mengarang. Bandung: Nuansa Cendekia.

JUFRI, J. (2007). Metode Penelitian Bahasa, Sastra dan Budaya.

Jufri, J. (2007). Metode Penelitian Bahasa. Sastra dan Budaya.

JUFRI, J. (2017). Strategi Pembelajaran Bahasa.

Junus dan Junus. (2011). Keterampilan berbahasa tulis. Makassar: Badan penerbit Universitas Negeri Makassar.

Mantasiah, R., Juffri, J., \& Yusri, Y. (2017). Keefektifan Model Pembelajaran Jaring Laba-Laba (Webbed) dalam Keterampilan Menulis Karangan Sederhana Bahasa Jerman. Indonesian Journal of Educational Studies, 20(2).

Maryana, Tri. (2014). Penggunaan Media Memori Games dalam Pembelajaran Kosakata Bahasa Jerman. Skripsi

Nurlina. (2015). Hubungan penguasaan Kosakata dengan keterampilan Menulis Karangan sederhana bahasa Jerman siswa Kelas XI Ipa MAN Bulukumba.

Purwanto, M. Ngalim. (2012). Prinsipprinsip dan Teknik Evaluasi Pengajaran. Bandung: PT Remaja Rosdakarya.

Qalbi, U. N., Mantasiah, R., Jufri, J., \& Yusri, Y. (2017). Efektivitas Model Pembelajaran Kooperatif Tipe Teams Games Tournaments dalam Keterampilan Menulis Bahasa Jerman Siswa Kelas XII IPA SMA Negeri 1 Bontonompo Kabupaten Gowa. Indonesian Journal of Educational Studies, 20(1).

Rahman, Niaryanti. (2015). Hubungan Antara Penguasaan Gramatik
Dengan Keterampilan Menulis Karangan Sederhana Bahasa Jerman Siswa Kelas XI SMA Negeri 2 Rantepao Kabupaten Toraja Utara. (Skripsi). Makassar: Jurusan Pendidikan Bahasa Jerman UNM.

Rismayanti Muslim. (2012). Hubungan Penguasaan Kosakata dengan Kemampuan Membaca Memahami isi Teks Bahasa Jerman Siswa Kelas XI Sma Negeri 2 Bontotiro Kabupaten Bulukumba. Makassar : FBS Universitas Negeri Makassar.

Romadloni, A., \& Mantasiah, R. Intercultural approach in foreign language learning to improve students' motivation. Senior Editors, 61.

Saud, Syukur. (2014). Pengembangan Model Pembelajaran Menulis Deskripsi Bahasa Jerman Berbasis Model Komunikasi SMCR Berlo di SMA. Program Pascasarjana Universitas Negeri Makassar, Disertasi.

Semi, M. Atar. (2007). Dasar-Dasar Keterampilan Menulis. Rev.ed. Bandung: Penerbit Angkasa.

Sugiyono. (2015). Metode Penelitian

Pendidikan Pendekatan Kuantitatif,

Kualitatif, dan R\&D. Bandung:

Penerbit Alfabeta.

Suparno, Yunus. (2010). Keterampilan Dasar Menulis. Jakarta: Universitas Terbuka.

Suriati. (1998). Penguasaan KK Bahasa Indonesia Siswa kelas III SLTP Batara Gowa Sungguminasa Kec. Somba Opu Kab. Gowa.FPBS-IKIP Ujung Pandang.

Tarigan, H.G. (2011). Pengajaran koskata (Edisi Revisi). Bandung:Angkasa. 
40 Eralingua: Jurnal Pendidikan Bahasa Asing dan Sastra Vol.2, No.2, August 2018

Tarigan, H.G. (2013). Menulis sebagai suatu keterampilan berbahasa (Edisi Revisi). Bandung:Angkasa.

Waridah, Ernawati. (2008). EYD dan Seputar Kebahasaan Indonesia. Jakarta: Kawan Pustaka.

Yusri, Y., Mantasiah, R., \& Jufri, J. (2018).
Model in English Teaching to Increase Student's Learning Outcome. Journal of Advanced English Studies, 1(1), 39-43.

Zainurrahman. (2011). Menulis Dari Teori Hingga Praktik. Bandung: Alfabet. The Use Of Two Stay Two Stray 